\title{
A comparative analysis of the smart money effect in Malaysian Islamic and conventional equity funds
}

\author{
Ainulashikin Marzuki ${ }^{\mathrm{a}}$ and Andrew C. Worthington ${ }^{\mathrm{b} *}$ \\ ${ }^{a}$ Faculty of Economics and Muamalat, Universiti Sains Islam Malaysia, Nilai, Malaysia; ${ }^{b}$ Department of \\ Accounting, Finance and Economics, Griffith University, Nathan, Australia
}

\begin{abstract}
This paper undertakes a comparative analysis of the 'smart money' effect in mutual funds-whereby investors are able to identify funds that subsequently perform well—in Malaysian Islamic and conventional domestic equity funds. We find that Islamic equity fund investors are unable to identify funds that will outperform benchmarks in the future. However, these same investors have some ability in identifying poorly performing funds and reallocating their funds accordingly. This contradicts our findings regarding their counterparts, such that conventional equity fund investors are generally able to identify better performing funds and modify their investments in light of this information. The key implications are as follows. First, Islamic equity investors naively chasing recently highly performing funds only incidentally benefit from mutual fund momentum strategies. Second, fund managers may be able to benefit from a contrary 'dumb money' effect found among Islamic equity fund investors in that they appear most concerned with only very poor performance in determining the flow of funds, not so much a lack of superior performance. Finally, we find high search costs may be one reason why investors naively chase past better performing funds.
\end{abstract}

Keywords: Islamic finance; mutual funds; fund flow-performance; smart money effect.

JEL codes: C23, G11, G20, M14.

Acknowledgements: The authors would like to thank an anonymous reviewer and participants at the Australasian Finance and Banking Conference held in Sydney, the International Islamic Finance Conference held in Abu Dhabi, the Malaysian Finance Association Conference held in Kuala Lumpur and the Indonesian Financial Management Association International Conference held in Yogyakarta for their helpful comments and suggestions.

*Corresponding author. Email: a.worthington@griffith.edu.au 


\section{Introduction}

Existing studies generally find that actively managed equity funds underperform their respective benchmarks and charge high management fees. However, seemingly despite this, actively managed equity funds have steadily increased in number and funds invested relative to index funds. Some studies have suggested that this is because of a so-called 'smart money effect', that is, the ability of investors to identify funds that are able to perform better in the future and then place money in these funds. Examples in developed markets include Gruber (1996) and Zheng (1999) in the US, Keswani and Stolin (2008) in the U.K, Vicente, Ortiz and Andreu (2008) and Andreu, Ortiz and Sarto (2008) in Germany and Spain, Gharghori, Mudumba and Veeraraghavan (2007), Gharghori, Sujoto and Veeraraghavan (2008) in Australia, and in emerging markets, Peng, Chen, Shyu and Wei (2011) in Taiwan. However, some other studies also find no evidence of a smart money effect in managed funds, including Sapp and Tiwari (2004) in the US and ul Haq, Khurshed and Espenlaub (2011) in the U.K and Renneboog, Ter Horst and Zhang (2008) in terms of socially responsible investment (SRI) funds worldwide. The evidence of smart money is thus not only limited but also mixed and this compels us to investigate if smart money exists in other national markets and for other types of mutual funds. In this regard, and to our best knowledge, no existing work examines the smart money effect in Malaysia and in the context of Islamic equity funds.

This paper investigates the smart money effect in Malaysia-a key emerging market with the largest number of Islamic equity funds worldwide (Marzuki and Worthington 2014). Our planned analysis closely follows the seminal method established in Sapp and Tiwari (2004). However, as an extension, we also investigate if there is difference in fund selection ability between the two key groups of investors, namely, Islamic equity fund (IEF) and conventional equity fund (CEF) investors. Our study involves conducting performance tests on new money portfolios. We employ two models to conduct the performance tests following Fama and French's (1993) three-factor and Carhart's (1997) four-factor models. In our approach, we analyse the performance of funds at aggregate level constructed on the previous year new money flow information to address the following two main questions. First, is there a smart money effect in either or both the Malaysian IEF and CEF industries. Secondly, is there any difference in fund selection ability between IEF and CEF investors? We employ Malaysian equity funds data for both IEF and CEF to explore the above research questions over the period 1999 to 2008. 
Before proceeding, an important comment is in order. First, most existing smart money studies employ monthly or quarterly money flow data on the basis that investors are active, relatively high-frequency traders. In this study, we are obliged to rely upon annual money flow data. This is because it is the only frequency available to investigate the flow of funds in Malaysia, as laboriously collected from the annual reports and prospectuses of the individual funds, a situation not unexpected in nearly all emerging markets where the mechanisms for collecting this information remain in their infancy. Nevertheless, the assumption that managed fund investors are also active traders, therefore motivating the use of higher frequency data, contradicts the established evidence regarding investor behaviour in most countries, including the US [see, for example, Ke (2006)]. Essentially, by employing less frequent data, we assume Malaysian investors switch funds only relatively occasionally. Our findings contrast strongly with the extant literature. On average, there is no evidence of a smart money effect (the identification of better performing funds) for Malaysian IEF investors over the period 1999 to 2008. This suggests that the Malaysian IEF investors exhibit no systematic fund selection ability. However, there is some evidence that IEF investors are instead able to identify poorly performing funds and disinvest from these funds accordingly. Conversely, there is a weak evidence of smart money in CEF investors.

This study is novel in at least three regards. First, even though the managed funds literature is quite extensive and well developed, it is highly concentrated in the area of their performance and performance persistence. Other aspects of managed funds, such as their governance and flow-performance relationships, are the focus of interest much less commonly. Moreover, as with research on the performance of managed funds, the existing research mainly focuses on developed markets in the US, the UK, Europe, and Australia, with fund flows in emerging markets comparatively under researched. Similarly, the research also heavily focused in the managed funds as a general with few comparative studies of conventional and other types of managed funds, including SRI funds and as here IEF. It is also appropriate to extend the techniques employed in developed markets (mostly the US) to emerging markets as well as other fund types.

Second, despite the growth of Islamic finance, research in this area remains relatively scarce. Islamic finance and IEF are the fastest growing segments of the global financial industry and within the Islamic financial system, respectively, with the number of Islamic funds worldwide increasing threefold from 200 funds in 2003 to 680 funds in 2008, (Eurekahedge, 2008). At the same time, the value of assets managed through Islamic mutual funds has grown from US\$20 
billion in 2003 to US\$44 billion in 2008 (Ernst \& Young, 2009). Of this, equity funds represent the largest (about 40 percent) segment of Islamic mutual funds, followed by fixed income (16 percent), real estate and private equity (13 percent), with the remaining funds in cash, commodities and other asset classes. Islamic mutual funds are found across the globe, including North America and Europe, more than half are based in the Middle East and the Asia-Pacific (International Financial Services London, 2010, p. 5). Nonetheless, very few studies specifically address the behaviour of Islamic depositors, borrowers and investors [for exceptions, see Abdullah et al. (2007), Ismail and Shakrani (2003), and Nathie (2009)]. This study thus provides useful information about not only a relatively unexplored segment (Islamic managed funds), but also new insights into the investor behaviour of a very sizeable global religious community (Muslims).

Finally, Malaysia is an interesting context to investigate the behaviour of Islamic fund investors. First, the development of Islamic finance in Malaysia was one of the earliest and fastest in Southeast Asia, albeit growing from a small base. Currently, Islamic banking is about one-fifth the size of conventional banking in Malaysia with takaful (insurance) assets representing about seven percent of the industry. While the Islamic mutual funds market is also relatively small though rapidly growing (in terms of net asset value about 13 percent of the industry), Malaysia has quickly become one of the key players in the world of Islamic fund management. Its unique capital market structure where Islamic financial system works in parallel with the conventional financial system provides a unique setting to study the behaviour of investors. The Malaysian market also has the largest number of individual Islamic mutual funds (more than 60 percent of the global Islamic fund market) and is second-largest in terms of the size of Islamic mutual fund assets under management (Abderrezak, 2008; Eurekahedge, 2008). Table 1 highlights the relative growth of Islamic and conventional mutual funds in Malaysia. It is then a good context to investigate both IEF and CEF, especially given the dearth of existing work concerning this setting.

\section{$<$ INSERT TABLE 1 HERE $>$}

The remainder of this paper is organised as follows. Section 2 briefly reviews the institutional setting of the Malaysian mutual fund industry. Section 3 reviews the existing literature on the smart money effect. Section 4 describes the data, Section 5 explains the research methodology, and Section 6 reports the results. Section 7 concludes the paper. 


\section{The Malaysian mutual fund industry}

The most important factor contributing to the introduction of Islamic mutual funds in Malaysia was the launch of the Skim Amanah Saham Nasional (ASN) [National Unit Trust Scheme] and the Amanah Saham Bumiputera (ASB) [Bumiputra Unit Trust] in the 1980s. The main objective of these funds was to encourage Bumiputra (native Malays as distinct from Chinese, Indian or other Malaysians) to participate in the corporate sector and to improve their socioeconomic standing. The success of these funds led to strong demand for Islamic mutual funds as most Bumiputra are also Muslims, with the first Islamic equity fund introduced in 1993 by the Arab-Malaysian Unit Trust Berhad, the Tabung Ittikal (the Ittikal Fund). Marzuki and Worthington (2014) discuss these developments in detail.

The Malaysian Islamic fund management industry has since grown from just two Islamic unit trust funds in 1993 to 136 funds, representing 25 percent of all 539 Malaysian mutual funds, with a combined net asset value (NAV) of RM16.41 billion (US\$5.03 billion) as at March 2008. Between 2003 and 2007, assets under management (AUM) in these Islamic funds increased by 44 percent, with exponential growth expected to continue with the increase in the number of Shariah (Islamic law) compliant stocks listed on the Malaysian and international stock markets. As at May 2008, 85 percent of all listed companies on the Bursa Malaysia were Shariah compliant, accounting for 64 percent or US\$193.3 billion of total market capitalization. Islamic mutual funds are therefore one of the most important components of the Malaysian Islamic financial system in general and the Islamic capital market in particular. Currently, Malaysia also has the largest number of Islamic mutual funds in the world comprising 152 funds managed by 39 fund families, and second only to Saudi Arabia in terms of total AUM. Marzuki and Worthington (2015) provide a useful analysis of the investment screening process in these funds.

Malaysia's success in this area lies in the integration of key structural components, namely the Islamic banking sector, Islamic debt capital and equity markets, Islamic money market, the Takaful industry, and a number of other peripheral Islamic institutions, and its regulatory infrastructure, including financial liberalization and government incentives to promote the Islamic fund management industry. Recent incentives include allowing foreign investors to own up to 70 percent of stockbroking companies (up from 49 percent) and foreign fund managers to establish 100 percent foreign-owned fund management companies in Malaysia. We can attribute the proliferation of Shariah compliant products and services, including 
Shariah mutual funds, to the strong support of the Malaysian government as well as concerted efforts by key market players, regulators, including the Securities Commission of Malaysia (SCM) and the Federation of Investment Managers Malaysia (FIMM), and several other financial intermediaries. This has led to a significant increase in the depth and breadth of the industry.

\section{Literature Review}

One of the dominant areas in the mutual fund literature is the study of fund flows. The bulk of this work investigates the relationship between cash flows into and out of mutual funds as a function of past performance and other fund characteristics. Another strand of literature in fund flows, which is the focus of this paper, investigating if mutual fund investors are able to identify future good performing funds in which to place their money and, alternatively, to move their money out of funds that subsequently perform poorly (Gruber, 1996; Sapp and Tiwari, 2004; Zheng, 1999). That is, are investors able to make value-enhancing decisions and not simply chase past performance. The key insight was first initiated by Gruber (1996) when he puzzled over why when the underperformance of actively managed mutual funds is so evident in the literature, the growth of this type of fund had been steadily increasing. Sampling 227 US equity funds over the period January 1985 to December 1994, Gruber found that new money flow into mutual funds enjoyed a significantly higher risk-adjusted return when compared with the average return for all investors in these funds.

Zheng (1999) repeated this study using a sample of US equity funds from 1970 to 1993 along with several more comprehensive performance metrics, including the Fama-French threefactor model and Shanken's (1990) conditional performance measure. Zheng (1999) found similar results to Gruber (1996), termed the “smart money” effect. However, Zheng (1999) also found the smart money effect was, however, temporary and largely but not completely explained by the strategy of chasing past winners (momentum). At the macro level, Zheng (1999) found that the smart money effect was not significant and uninfluenced by macroeconomic information or style effects. Investors may thus use past cash flow information in small funds to choose those that will outperform in subsequent periods as the smart money effect is generally more pronounced in small funds. Zheng (1999) documented that past performance attracts heavy money flows and funds that receive high money flows perform significantly better than those that lose money. However, according to Zheng (1999) this effect is short lived and that a 'betting the winner' strategy explained much of the results. 
Later, Sapp and Tiwari (2004) considered US equity funds from 1970 to 2000. Unlike the two earlier studies, they found no smart money effect after controlling for Jegadeesh and Titman (1993) type price momentum. However, this does not arise when Keswani and Stolin (2008) employed the same four-factor performance measurement, including a momentum factor, in their smart money analysis. Using data on funds from 1991 to 2000 Keswani and Stolin (2008) concluded that smart money was evident in the UK market. The analysis also revealed that the smart money effect was stronger when using monthly instead of quarterly intervals. Another advantage of this study was that they used actual flow data into and out of the fund instead of money flow calculated from changes in net asset value or asset returns. Other studies that have not identified the smart money effect include Ke (2006) and ul Haq et al. (2011).

In subsequent work, Frazzini and Lamont (2008) employed longer sample periods and found that money flows are in fact best explained by 'dumb money': investors chasing past high performers, not future better performers. By actively reallocating funds across different mutual funds, existing investors experienced significantly decreasing wealth in the long term. As for SRI funds, Renneboog, et al. (2008) documented that SRI investors are not smart in selecting future performing funds. This is because funds that attract most flows are not generating higher returns. This is due to decreasing returns to scale where heavy money flows to mutual funds will increase performance but at a slower rate and, finally, deteriorating. This implies that ethical money is not financially smart in the sense that the mutual fund reallocation decisions of SRI investors reduce their wealth.

Wermer (2003) investigates the reasons behind the outperformance of funds that receive high cash inflow by examining fund portfolio holdings. Supporting findings of Sapp and Tiwari (2004) he finds that investors are merely chaser of past fund performance and they incidentally benefit from momentum returns. He also observes that the magnitude of momentum earnings is much larger than previously thought. He concludes that managers of outperforming funds receive higher cash inflows and then invest further these cash inflows in momentum stocks so these funds continuously earn good performance. In contrast, managers of underperforming funds are reluctant to dispose the losing stocks to purchase new momentum stocks. This behaviour is termed as disposition effect by Odean (1998). This explains why momentum stocks are the reason of winning funds continues to earn favourable returns compared to losing funds for a much longer period from other studies. 
As there is strong evidence that supports that there is a flow performance relationship, Edelen (1999) investigated whether there is a relationship between fund flow and future return. He argued that the liquidity offered to investors obliges fund managers to purchase new assets, which they would not necessarily have bought had the fund not experienced an inflow. The general argument is that this liquidity-motivated trading reduces fund returns. Greene and Hodges (2002) also argued that fund flow had a negative impact on fund returns the following day, especially for international funds but not domestic funds. Yet again, while there is contradictory (inconclusive) evidence in the relationship between fund flows and future performance in conventional mutual funds, there is no available evidence concerning Islamic mutual funds.

\section{Data}

We investigate the presence of 'smart money' in Malaysian IEFs and CEFs over the sample period from January 1999 to December 2008. We focus on equity funds for two main reasons. First, as shown in Table 2, these funds represent the largest number of both IEFs and CEFs operating in Malaysia. Second, these funds exhibit consistency in overall asset allocation and the applicability of asset pricing models. Our main data sources are the Morningstar (2010) database and the annual reports and prospectuses of the funds. We collect monthly returns data from Morningstar. All other information, including assets under management (AUM), the management expense ratio (MER), portfolio turnover ratio (PTR), equity holdings, and the number of funds in the fund's family are from the annual reports and prospectuses.

\section{$<$ INSERT TABLE 2 HERE $>$}

We sample 117 Malaysian equity funds with equity holdings of at least 65 percent by marketvalue weight. This comprises 34 IEFs and 83 CEFs. The number of funds varies over time through the creation of new funds and the merger of existing funds, with the minimum number of funds in any year being five IEFs and 31 CEFs. We refine our sample using the following procedure. To start with, for any given year $t$, we excludes funds that involved in a merger in year $t, t+1$ or $t+2$. We do this because the receipt of assets by the acquiring fund from the acquired fund through merger will distort the observed flow of funds. Consequently, we remove fund-year observations from the sample during the merger year. 
Another potential problem is that the sample may suffer from survivorship bias whereby we inadvertently exclude failed funds from the sample because they no longer exist. Two considerations are in order. First, our sample is already small given the nature of the developing market examined and further adjustment of the sample to counter survivorship bias would not improve this situation. Second, the short investment horizon and the fact that nearly all of the funds removed from our sample are through merger suggest such adjustments may not be necessary. Finally, we follow Chevalier and Ellison (1997), Goetzman and Peles (1997) and Sirri and Tufano (1998) in arguing a priori that with mutual funds flow study, there is no significant difference in results when performing analyses on a survivorship bias-free or survivorship bias sample.

Table 3 provides summary statistics for the sample of IEF and CEF from 1999 to 2008. For IEF, the mean and median fund sizes are RM157.99 and RM62.32 million, respectively. For CEF, the mean and median fund sizes are 158.32 million and RM75.23 million, respectively. This indicates that CEF are slightly larger than IEF. The mean and median yearly net cash flows are RM-0.11 and RM-0.91 million respectively for IEF and RM-19.13 and RM-5.92 million respectively for CEF. Clearly, in terms of the absolute flow of funds, CEF exhibited larger negative net flows than IEF. But in percentage terms, the mean and median percentage flows were respectively 13.47 and -1.50 percent for IEF and -2.63 and -10.27 percent for CEF which in contrast with the value of RM net money flows. As with RM money flows, the mean and median percentage net money flows for both types of funds were negative, indicating that both types of funds experienced larger outflows than inflows in the sample period.

\section{$<$ INSERT TABLE 3 HERE $>$}

The mean management expense ratio (MER) for IEF and CEF are 1.77 percent and 1.75 percent, respectively, with standard deviations of 0.69 for IEF and 0.98 for CEF. This indicates that the dispersion of MER for IEF is relatively smaller. The average PTR for IEF and CEF is approximately equal; however, the standard deviation of PTR is larger for IEF compared with CEF (151.63 vs. 70.67 percent, respectively). This indicates that there is greater variation in the number of times investments turnover in IEF funds than in CEF funds. PTR for CEF is more stable than IEF.

$<$ INSERT TABLE 4 HERE $>$

$<$ INSERT TABLE 5 HERE $>$ 
Table 4 and Table 5 detail the number of IEF and CEF, respectively, in each year of the sample period. As shown in Table 4, the minimum and the maximum number of IEF funds in the sample period are five in 1999 and 33 in 2008. Out of five funds in 1999, three funds receive positive flows while 2 funds receive negative flows. In 2008, out of 33 funds, 16 funds receive positive flows, while 17 funds receive negative flows. The largest net positive and net negative money flows are RM86.40 million in 2001 and RM87.55 million in 1999. Interestingly, only on four occasions do these positive net money flows earn higher average excess returns in the following years when compared to the negative net money flows. This suggests that IEF investors are unable to earn higher average excess returns for the money put into IEF portfolios in comparison to investors divesting from IEF portfolios.

As shown in Table 5, the minimum and the maximum number of CEF funds in the sample period are 31 in 1999 and 77 in 2006, respectively. Out of 31 funds in 1999, 13 funds receive positive flows while 18 funds receive negative flows. In 2006, out of 77 funds, 7 funds receive positive flows, while 70 funds receive negative flows. The largest net positive and net negative money flows are RM71.96 million in 2000 and RM83.23 million in 2007. In nearly all of the sample years, investors earn higher average excess returns for money invested in the CEF portfolio when compared to investors who disinvest. We consider this further in the following two sections.

\section{Empirical method}

Several measures are important in analysing the existence of smart money. The main considerations are the need to define flows measures and performance measures as explained further in the following subsections. In this study, we evaluate the performance of mutual fund investors by assessing the performance of their aggregate fund flows. Essentially, we estimate their flows and then track the performance of the different money flow portfolios.

\section{Fund flow measures}

Similarly, to the extant literature, we employ a standard procedure in constructing the flow of funds in that we use implied flows instead of the actual amount money flows into and out of mutual funds. We employ two different measurements of implied flows: the absolute amount of money flows (in Ringgit Malaysia (RM)) and normalised money flows (the growth rate of money flows). The RM amount of money flow is defined as the annual change in assets under management (AUM) net of fund returns $\left(R_{i t}\right)$ during the period and is calculated as: 
$\mathrm{RM} \mathrm{FLOW}_{i, t}=A U M_{i, t}-A U M_{i, t-1}\left(1+\operatorname{RET}_{i, t}\right)$

where $A U M_{i, t}$ is total assets under management for fund $i$ at the end of year $t, A U M_{t-1}$ is total assets under management for the fund $i$ at the end of year $t-1$, and $R E T_{i, t}$ is the raw return for fund $i$ during year $t$ (we convert the monthly return in the Morningstar database to a yearly holding return).

To take into account of the size of the mutual funds, we also calculate percentage or normalised net money flows (as the results are similar, we report the results only using RM flows). With this measure, we divide the money flow by the previous year's AUM as follows:

$F L O W_{i, t}=\frac{A U M_{i, t}-A U M_{i, t-1}\left(1+R E T_{i, t}\right)}{A U M_{i, t-1}}$

As we do not know the exact movement of investment during the holding period, we need to make underlying assumptions as follows. First, we assume that all new money invested or withdrawn from the fund along with the reinvestment of dividends takes place at the end of the period when computing the flows. Second, we assume that the net flows into and out of the fund do not affect the fund's return during the period in which the money flow is measured. These assumptions are similar to the work in Gruber (1996) and Zheng (1999). As discussed earlier, we employ annual flows instead of the monthly or quarterly flows as frequently used in other studies, the principal reason being that only annual data is available.

\section{Portfolio construction}

In order to evaluate fund selection ability among Malaysian investors, we construct several portfolios based on the previous year money flows. This method is identical to the approach in Zheng (1999), referred to there as the portfolio approach. We construct new money portfolios as follows. At the beginning of each year, and based on the previous yearly net money flows of funds, we separate the sample of mutual funds into positive and negative net new money portfolios. Positive new money flow portfolio contains all funds, which experience positive money flow in the previous year while negative new money portfolio contains all funds, which experience negative new money in the previous year. We also divide all funds in the sample into high and low new money portfolios. We use median value as the cut-off point to separate funds with high and low net money flows. We also construct average all fund portfolios as benchmark to compare the performance of the above portfolios. We use three types of weighting scheme to construct those portfolios. These are equally weighted, value weighted and cash flow weighted. We calculate equally weighted portfolio returns for positive and negative net money flows, average all fund portfolio and for high and low net money flow 
portfolios. We also calculate value (AUM) weighted portfolio returns for positive and negative net money flows and average all fund portfolios. Finally, we only calculate cash flow weighted return for positive and negative net new money portfolios.

In total, we construct ten types of portfolios as follows:

\begin{tabular}{ll}
\hline Portfolios & Descriptions \\
\hline EW average & Equally-weighted average portfolios of all available funds \\
VW average & Value (AUM)-weighted average portfolios of all available funds \\
EW positive flows & Equally-weighted of all available funds with positive money-flows \\
EW negative flows & Equally-weighted of all available funds with negative money-flows \\
VW positive flows & $\begin{array}{l}\text { AUM or value-weighted of all available funds with positive money-flows (also } \\
\text { called as positive old money-flows) }\end{array}$ \\
VW negative flows & AUM or value-weighted of all available funds with negative money-flows (also \\
MW positive & called as negative old money-flows) \\
MW negative & Money-flow weighted of all available funds with positive money-flows \\
High flow & Money-flow weighted of all available funds with negative money-flows \\
Low flow & Equally-weighted of all available funds with money-flows above median \\
\hline
\end{tabular}

Throughout the remainder of the analysis, we determine the performance of mutual fund investors by comparing the return performances of these ten portfolios.

\section{Portfolio performance measures}

We estimate the risk-adjusted return of the above portfolios using a time-series regression approach. This approach starts by calculating the time series of raw returns for each of the ten portfolios and performing OLS regressions to estimate portfolio factor loadings and alpha estimates from three and four-factor model equations. Following Sapp and Tiwari (2004), the performance of the fund portfolios is evaluated by analysing the intercepts (alpha values) from regressions of the two-asset pricing models. If the alpha value is close to zero (and statistically insignificant), it implies that the model explains the returns on the fund portfolios.

If the estimated alpha is positive/negative (and statistically significant) for the positive/negative portfolios, respectively, it implies that the model does not explain the returns on the test portfolios and that the smart money effect exists. Significantly positive alpha for positive cash flows indicates that new investors tend to select funds that subsequently perform well. In addition, a significantly positive alpha for negative cash flows indicates that investors may realize their gains too soon. Hence, an assessment of whether the smart money effect exists will be made using the alpha values from a three-factor (Fama and French, 1996) and fourfactor (Carhart, 1997) model. The respective equations for these performance measures are:

$R_{i, t}-R_{f, t}=\alpha_{i}+\beta_{i}\left(R_{m, t}-R_{f, t}\right)+\beta_{S, i} S M B_{t}+\beta_{V, i} H M L_{t}+\beta_{M, i} M O M_{t}+\varepsilon_{i, t}$ 
where $R_{i, t}$ is the average monthly fund returns, $R_{f, t}$ is the risk-free rate; $R_{m t}$ is market returns, SMB is the fund allocation size estimator, HML is the fund allocation book-to-market estimator, $\mathrm{MOM}$ is the fund allocation momentum estimator, $\beta_{M i}$ is a measure of the sensitivity of the fund to the market, $\beta_{S i}$ is a measure of the fund exposure to the size of securities (a positive coefficient implies a sensitivity to small-cap stocks), $\beta_{V i}$ is a measure of the fund's exposure to value or growth securities (a positive coefficient implies exposure to high bookto-market securities), $\beta_{M, i}$ is a measure of the fund's exposure to contrarian or momentum strategies (a positive coefficient implies exposure to momentum strategies), $\alpha_{i}$ is a measure of stock selection ability (if positive the fund has superior stock selection ability), and $\varepsilon_{i t}$ is random error.

As Fama-French factors (SMB and HML) and Carhart's (1997) momentum factor (MOM) returns are not publicly available for countries outside the US, especially for emerging countries like Malaysia, we rely on the online research tool provided by Style Research Ltd. to construct monthly returns for these factors and the market factor $(M K T)$. The construction of the benchmark factors draws on the Worldscope database. Because of this limitation, we use the same benchmark for both portfolios, IEF and CEF. This method is similar to the earlier work by Bauer, et al. (2005), Renneboog, et al. (2008) and Hoepner, et al. (2009).

Market excess return $\left(R_{m, t}-R_{f, t}\right)$ is calculated as the return of a value-weighted portfolio of all stocks in Malaysia (including 'live' and 'dead' companies) available in the Worldscope database (the market wide equity index supplied by Worldscope database aims to cover 98 percent of market capitalisation) minus the risk-free rate, as represented by the three-month Malaysian Treasury bill rate. The size factor (small-minus-big or $S M B_{t}$ ) is the return difference between portfolios of small and large stocks. The small portfolio is the lower half of the portfolio of stocks ranked by market capitalisation. The book-to-market factor (high-minuslow or $H M L_{t}$ ) is the difference between the return of the top-30 and bottom-30 percent of stocks ranked according to the book-to-market ratio.

The momentum factor $\left(M O M_{t}\right)$ is the difference between the top-30 and bottom 30-percent of the portfolio of stocks ranked based on prior return. All of the factors are value weighted and constructed using one-month lagged information. Consistent with Fama and French (1993) and Carhart (1997), the size and the book-to market factors are rebalanced at the end of June of each year, while the momentum factor is rebalanced at the end of each month. According to 
Renneboog et al. (2008), these factors are virtually identical to the Fama-French factors using the CRSP database.

This study uses the three-month Malaysian Treasury bill rate as a proxy for risk free rate. This data is available from the Monthly Statistical Bulletin published by the Bank Negara Malaysia (Central Bank of Malaysia). This is an annualised holding period yield on a three-month Treasury bill and therefore is converted to a monthly equivalent consistent with the monthly returns of the mutual funds and the market's return. The monthly equivalents of the annualised yield is estimated as a geometric mean as follows (equivalent continuously compounded monthly rate).

\section{$(1+\text { Annualised Yield })^{1 / 12}-1$}

(4)

\section{Empirical results}

This paper develops the smart money effect following Gruber (1996), Zheng (1999) and Sapp and Tiwari (2004). The risk-adjusted returns of new money portfolios are measured using Fama and French (1996) three-factor alpha and Carhart’s (1997) four-factor alpha.

Table 6 presents descriptive statistics for all new money portfolios over the period 2000 to 2009. The table provides mean monthly returns in excess of risk-free rate (the 3-month Malaysian Treasury bill rate), median, and standard deviation for Islamic and conventional equity fund investors, monthly excess market return, as well as the risk-free rate. We note that positive cash flow portfolios have a higher average return compared to negative cash flow portfolios for all portfolios regardless of the weighting method used. However, none of the positive portfolios has mean excess returns higher than the mean of excess market return. This indicates that the excess returns for all portfolios including average portfolio of all funds, asset weighted portfolio of all funds and portfolios constructed based on previous money- flows are unable to outperform excess market returns.

\section{$<$ INSERT TABLE 6 HERE $>$}

We divide the results into three main analyses. These are (1) performance of positive versus negative new money-flows; (2) performance of new versus old money-flows and (3) performance of high versus low money-flows. We use two performance models to measure the performance of these portfolios. These are: (1) the three-factor and (2) the four-factor 
models. Sapp and Tiwari (2004) find that incorporating momentum factor makes the value of alpha of the portfolios as well as the different portfolios become smaller in magnitude and insignificant. Because of this effect, we focus our discussion mainly on the results obtained using the Carhart (1997) four-factor model. Due to space constraints, we limit our discussion to the alpha and omit other variables such as SMB, HML and MOM.

\section{Performance of positive new money versus negative new money}

Table 7 presents the alpha estimates of the Fama-French (1993) three-factor and the Carhart (1997) four-factor models of positive and negative new money-flow portfolios for Malaysian IEFs (columns 2 to 4), CEFs (columns 5 to 7) and the differences in the estimates between IEFs and CEFs (columns 8 to 10). In Panel A, we construct these money-flow portfolios based on the previous year net money-flows (positive or negative) and weighted equally by the number of funds in the portfolio. The table also reports the equally-weighted average portfolios, the difference in the estimated alphas between the positive and negative portfolios, and between positive and average portfolios. Panel A.1 and Panel A.2 present the alpha estimates of the three-factor and four-factor models, respectively. We identically arrange the alpha estimates of these money-flow portfolios in Panel B except that we use money-flow weighted instead of equally-weighted, and the average all fund portfolio is the average portfolio weighted by the value of the asset under management (value-weighted average portfolios).

\section{$<$ INSERT TABLE 7 HERE $>$}

We start with Panel A in Table 7 for equally weighted portfolios. Looking at the three-factor model, the alpha of positive money-flow portfolio earns 3 basis points per month while the alpha for negative money-flow portfolio earns -10 basis points per month. Even though the signs of each portfolio indicates that investors exhibit fund selection ability (moving money to funds that are performing well and disinvest from funds that are performing poor subsequently), the results are not statistically significant. The alpha of the average portfolio is -3 basis points per month and insignificant. The results indicate that none of the strategies is able to earn either significantly positive or negative alphas.

Next, we compare the positive money-flow with negative money-flow as well as with the average portfolio. We find the difference between the alphas for the former two portfolios and the latter two portfolios are statistically insignificant, 13 and 6 basis points each per month, respectively. Hence, the so-called 'smart money' effect does not exist among IEF 
investors. Even when we take the difference between the positive new money flows and average all fund portfolios, we only obtain a six basis point difference, which is also statistically insignificant.

When we control for return momentum in the four-factor model, we note that the value of alphas has shrunk compared with the value of alphas in the three-factor model. For instance, the alpha for positive and negative money-flow portfolios shrinks to -3 and -18 basis points per month, respectively. The corresponding four-factor alpha for the average portfolio equals to an insignificant -9 basis points. Similarly, we note that the alpha for the difference between the positive and negative money-flow portfolios is smaller (9 basis points per month) than from alpha of the same portfolio in the three-factor model. The same goes when we compare the positive money-flow and average portfolios, amounting to 7 basis points per month. In summary, the results for the equally-weighted money-flows portfolios for IEF investors shows that there is no 'smart money' effect present in either the three- or four-factor models.

We next examine the performance of money-flow portfolios that use money-flow weighting scheme, as reported in Panel B in Table 7. Unlike an equal-weighting scheme, a money-flowweighting scheme has the benefit of placing greater emphasis on funds experiencing the largest absolute money-flows. The three-factor alphas for the positive and negative moneyflow portfolios are 10 and -5 basis points per month, respectively and insignificant. The average portfolio (value-weighted) has essentially zero basis points per month. The 'difference' portfolio of positive minus negative money-flows) is insignificantly 15 basis points per month. Interestingly, the estimated alpha for the 'difference' portfolio of positive money-flow and average portfolios is 10 basis points and significant at the 10 percent level. This indicates a weak presence of ‘smart money' effect among IEF investors based on the money-flow weighted portfolios, which suggests that IEF investors who choose to invest in IEFs portfolio earn higher risk-adjusted return than the average investors who naively invest in all IEFs.

When controlling for return momentum, and similarly to our experience with equallyweighted portfolios, the alpha values fall. The four-factor alphas for the positive and negative money-flow portfolio shrink to 5 and 9 basis points per month respectively. The four-factor alpha for average portfolio also shrinks to -2 basis points per month. However, all results are insignificant. We next examine the alphas of the difference between the 
positive and the negative money-flow portfolios as well as between the positive moneyflow and average portfolios. Using the four-factor alpha, there is no significant difference between these two pair of portfolios. This indicates the presence of 'smart money' in IEFs with the three-factor model disappears when the four-factor model is used. This result supports the work of Sapp and Tiwari (2004). In summary, we conclude that there is no 'smart money' present in Malaysian IEFs using both equal weighted and money-flow weighted methods.

We next examine the ability of CEF investors to predict future fund performance, which we present in columns 5 to 7 . Using equally weighting scheme, the three-factor alpha for the positive and negative money-flow portfolios are 4 and -7 basis points per month, respectively. Even though the sign indicates that positive and negative money-flow portfolios yield positive and negative returns respectively, both are insignificant. The alpha for the average portfolio is -5 basis points per month. The 'difference' portfolios between positive and negative money-flows as well as between positive and average are 11 and 10 basis point per month, respectively, and are not significant.

For the four-factor model, the alphas for positive and negative money-flow portfolios decrease to -3 and 10 basis points per month, respectively. The alpha for the average portfolio is -10 basis points per month. Comparing positive and negative money-flow as well as positive money-flow and average portfolios, both earn 7 basis points per month and are insignificant. It is interesting to find that using money-flow weighted portfolio, positive money-flow gives a significant (at the 5 percent level) alpha of 7 basis points per month. Both negative money-flow and average (value-weighted) portfolios yield alphas of zero. These result in the alphas for both difference portfolios (between positive and negative money-flow and, between positive money-flow and average) significantly (at 5 percent level) 8 basis points per month. Both Gruber (1996) and Zheng (1999) found similar results in the three-factor model which support the presence of 'smart money'.

The four-factor model alpha for positive money-flow portfolio remains significant at 10 percent level, even though the alpha reduced to 6 basis points per month. The negative money-flow and average portfolios are -1 basis point and essentially zero per month, respectively. The alphas for the difference portfolios between positive and negative moneyflow, and between positive new money-flow and average are similar, 7 basis points per month (significant at the 10 percent level). These results indicate that even though both 
models produce decreased alpha values and significance levels, the presence of 'smart money' is evident among CEF investors. This is in contrast to Sapp and Tiwari (2004) who found disappearance of 'smart money' effect after controlling for the momentum factor. In summary, we can conclude that there is a strong evidence of 'smart money' in CEF investors using money-flow weighted portfolios.

\section{Performance of new money flow portfolio versus old money flow portfolio}

We repeat the above analysis by comparing new and old money-flow portfolios. Old money flow portfolio consists of the same funds except we weight the portfolio by the total assets of each fund at the beginning of the year instead of the corresponding cash flows at prior year. We start with the results for IEF investors followed by those for CEF investors and then evaluate how the fund selection abilities of these different sets of investors differ.

Table 8 presents the alpha estimates of the Fama-French (1993) three-factor and Carhart (1997) four-factor models of new and old money-flow portfolios for Malaysian IEFs (columns 2 to 4), CEFs (columns 5 to 7) and the differences in the estimates between IEFs and CEFs (columns 8 to 10). Panel A reports the positive new money-flow, positive old money-flow and the difference in the estimated alphas between the positive new and old money-flow portfolios. The positive new money-flow portfolios are the money-flow weighted of all available funds with positive money-flow. The positive old money-flow portfolios are the value (asset under management (AUM))-weighted (previous year AUM before the addition of new money-flow) of all available funds with positive money-flow portfolio. The old money-flow represents existing funds in the portfolio. We construct these new money-flow (positive and negative) portfolios based on the previous year net moneyflows. Panel A.1 and Panel A.2 present the alpha estimates of the three-factor and fourfactor models, respectively. We identically arrange the alpha estimates in Panel B except that we use negative money-flow instead of positive money-flow portfolios.

\section{$<$ INSERT TABLE 8 HERE $>$}

The three-factor alphas for the positive new money-flow and positive old money-flow portfolios are 10 and 9 basis points per month, respectively (statistically insignificant). The alpha for the 'difference' portfolio between new and old money-flow portfolios is essentially zero. We repeat the above using the four-factor model, the alpha for these portfolios (new money-flow, old money-flow and new versus old-money-flow) reduced slightly and remain insignificant (5, 4 and 1 basis points per month, respectively). 
We obtain similar results when repeating the above estimations (the three and four-factor models) on the negative money-flow portfolios, which also comprise the new, the old and the new versus old money-flow. All estimations yield insignificant alpha (see Panel B in Table 8). We conclude that there is no presence of 'smart money' using these models.

We present the results of CEFs in columns 5 to 7 in Table 8. The three-factor alphas for the positive new money-flow and positive old money-flow portfolios are 7 and 6 basis points per month (significant at 5 percent level), respectively. The alpha for the difference between positive new and old money-flow portfolios is one basis point per month (significant at 10 percent level). This indicates that the CEF investors are smart in the sense that investors who put new money in these funds earn slightly higher returns than existing investors in these funds.

However, the four-factor alpha for the positive new money-flow portfolio shrinks to 6 basis point per month (significant at the 10 percent level). Similarly, the four-factor alphas for the positive old money-flow and the difference between positive new and old money-flow portfolios shrink to 3 and 1 basis points per month, respectively. Our results support the work of Sapp and Tiwari (2004) where the evidence of 'smart money' in the three factor alpha no longer exists when we include the momentum factor.

The three-factor and four-factor alphas for the negative new and old money-flow portfolios are not significantly different from zero. Thus, the three- and four-factor alphas for the difference portfolio between negative new and negative old money-flow portfolio are also not significantly different from zero. We suggest that CEF investors are able to move money into CEFs, which become better performing funds in the future. However, their disinvestment strategy is not effective. In contrast, IEF investors naively invest in and disinvest from IEFs.

\section{Performance of high versus low money flow portfolio}

We next compare the alphas of high and low money flow portfolios. We again repeat the above analysis to the high and low money flow portfolios and examine the difference between these portfolios. We start with the results for IEF then followed by CEF investors and finally how the fund selection ability of these investors differs.

Table 9 presents the alpha estimates of the Fama-French (1993) three-factor and Carhart (1997) four-factor models of high and low money-flow portfolios for Malaysian IEFs 
(columns 2 to 4), CEFs (columns 5 to 7 ) and the differences in the estimates between IEFs and CEFs (columns 8 to 10). The table also reports the equally-weighted average portfolios, the difference in the estimated alphas between the high and low portfolios, and between high and the equally-weighted average portfolios. We construct these new money-flow portfolios based on the previous year net money-flows. The high money-flow portfolio refers to the portfolio consists of funds with net new money-flows above the median value for a particular year. Likewise, the low money-flow portfolio refers to all other funds that do not fit the previous criteria. Panel A and Panel B present the alpha estimates of the threefactor and four-factor models, respectively.

\section{$<$ INSERT TABLE 9 HERE $>$}

We start by analysing the high and low money flow portfolio for IEF investors using the threefactor model. We find that both high and low money-flow portfolios, even though giving favourable positive value for high and negative value for the low money-flow portfolios, the three-factor alphas are essentially zero ( 3 and -10 basis points per month, respectively). The three-factor alpha for average portfolio is -3 basis points per month. The different portfolios for both between high and low money-flow, and between high money-flow and average give insignificant alpha values (13 and 6 basis points per month, respectively), which are equivalent to zero.

However, using the four-factor model, there are different and interesting results. While high money-flow portfolio reduced to a zero alpha, the low money-flow portfolio reduced from insignificant -10 insignificant to significantly -19 basis points alphas per month. This results in significant alpha value of 19 basis points for the different portfolio between high and low money-flow portfolios (significant at 10 percent significant level). However, the value of alpha is not significant for the 'difference' portfolio between high and average portfolios. These results indicate that even though IEF investors do not exhibit 'smart money’ effect, on average, they are smart in moving away from non-performing funds.

For the CEF investors, we find that the three-factor alphas for the high and low moneyflow portfolios are -2 and -8 basis points per month, respectively, both with insignificant $p$-values. The three-factor alpha for the average portfolio is -5 basis points per month. Both, the different portfolio between high and low money-flow and between high and average portfolios are 6 and 3 basis points per month, respectively, with both insignificant $p$-values. 
Similar with the previous portfolios, with four-factor model, the alpha values reduced to 8 and -11 basis points for high and low money-flow portfolios, respectively. Even though we get significant negative result for the low money-flow portfolio, the four-factor alpha for the difference portfolio between high and low money-flow portfolios is insignificant (3 basis points per month). The difference portfolio between high money-flow and average portfolios is also not significant (2 basis points per month).

Based on this approach, CEF investors do not appear smart in indentifying funds that will be performing well above the average investors. However, there are some indications that they are able to move out their money from funds that are performing poor subsequently. However, their strategy do not results in significant gain as the estimated alpha between high and low as well as high and average is both insignificant.

\section{The difference in fund selection ability between IEF and CEF investors}

We construct 'difference' portfolios to determine if there is a difference in fund selection ability between IEF and CEF investors for all groups of portfolios. A 'difference' portfolio is the difference in monthly return between IEFs and CEFs in each of the 10 portfolios. Then, we repeat all the same analyses on these 'difference' portfolios to determine the difference between fund selection ability between these two groups of investors. This method is similar to Renneboog et al. (2011). We find that the differences in alphas are not statistically significant from zero between all trading strategies (refer to the last three columns in Table 7, Table 8 and Table 9). We conclude that even though the 'smart money' effect exists in the CEF portfolios, the difference is not significant when compared with the IEF portfolios.

\section{Discussion and conclusion}

In this paper, we consider the presence of 'smart money' effect in Malaysian IEF and CEF investors. The hypothesis is whether Malaysian IEF investors are able to identify funds that will outperform benchmark factors in the future or if these investors are able to anticipate mutual fund returns by directing money into funds that subsequently give superior returns. In addition, we investigated if there is any difference between IEF and CEF investors. We found that there is no evidence of a 'smart money' effect that could explain the tremendous growth of IEFs in Malaysia in general and among IEFs in particular. However, investors exhibited some fund selection ability in identifying IEFs that perform poorly in subsequent 
year. Conversely, although the results are mixed, we concluded that there is weak evidence that CEF investors are smart on average and are able to select funds that are able to perform well in the future.

We contribute to the literature by presenting several new findings. First, this is the first study that investigates the presence of 'smart money' in the Malaysian IEF industry and compares the abilities of IEF and CEF investors in this regard. Similar to Renneboog et al. (2011) in SRI funds, we found that the smart money is not present in the Malaysian IEFs. Comparing IEF and CEF investors, we found that CEF investors unlike IEF investors have some ability to select funds that are able to perform well in the future. Thus, only CEF investors possess fund selection ability overall.

Second, these findings significantly improve our understanding of the behaviour of investors in the mutual fund industry in Malaysia where Islamic capital market is part of the broader conventional market. The lack of smart money effect may be attributable to the following. First, the growth of the mutual funds in Malaysia in general and IEFs in particular is mainly due to support from government in the form of tax benefits, liberalisation that favour IEFs and other favourable regulations. Second, Malaysian investors may not be as sophisticated (or informed) as investors in larger capital market, such as the US, the UK and Australia. Finally, the frequent name changes and disappearance of existing funds due to mergers as well as frequent introduction of new funds in the Malaysian mutual fund industry may also contribute to an insignificant 'smart money’ effect for Malaysian mutual funds.

There are three main limitations in this study. First, while the data represents a large sample of Islamic and conventional domestic equity funds, it may not be representative of the Islamic equity funds as a whole. Therefore, caution needs to be exercised in drawing conclusions or inferences in relation to the broader market of Islamic funds. The sample size is rather small and only limited to a single developing country. Second, in relation to flow measures, the study only use implied flows while recent studies have used the individual components of flows (inflows and outflows).

Finally, we only have access to annual data for assets under management (AUM) and net asset value (NAV) in Malaysia. This problematic in that most other research on mutual fund flows uses either monthly or quarterly data, with some studies finding that mutual fund investors make decisions at frequencies that are closer to monthly than annually. As highlighted by 
Keswani and Stolin (2008), when comparing the results using monthly and quarterly data, quarterly (less frequent) data makes it much more difficult to detect fund-selection ability relatively to monthly data. This could explain some of our results.

\section{References}

Abderrezak, F. 2008. The Performance of Islamic Equity Funds: A Comparison to Conventional Islamic and Ethical Benchmarks. Masters thesis, University of Maastricht.

Abdullah, F., Hassan, T. and Mohamad, S. 2007. "Investigation of Performance of Malaysian Islamic Unit Trust Funds”. Managerial Finance 33 (2): 142-153.

Andreu, L., Ortiz, C. and Sarto, J. L. 2008. The Smart Money Effect in Two Major Mutual Fund European Industries. Paper presented at the Seminar in Finance CEMPRE/ CETE, Universidade Do Porto.

Bauer, R., Koedijk, K. and Otten, R. 2005. "International Evidence on Ethical Mutual Fund Performance and Investment Style”. Journal of Banking and Finance 29 (7): 17511767.

Carhart, M. M. 1997. “On Persistence in Mutual Fund Performance”. Journal of Finance 52 (1): $57-82$.

Chevalier, J. and Ellison, G. 1997. "Risk Taking by Mutual Funds as a Response to Incentives”. Journal of Political Economy 105 (6): 1167-1200.

Edelen, R. M. 1999. "Investor Flows and the Assessed Performance of Open-end Mutual Funds”. Journal of Financial Economics 53 (3): 439-466.

Ernst \& Young. 2009. The Islamic Funds \& Investments Report: Surviving and Adapting in a Downturn (3rd Ed.). Dubai: Middle East Global Advisors.

Eurekahedge. 2008. Hedge Fund Monthly: Key Trends in Islamic Funds. Retrieved from http://www.eurekahedge.com

Fama, E. F. and French, K. R. 1993. "Common Risk Factors in the Returns on Stocks and Bonds”. Journal of Financial Economics 33 (1): 3-56.

Fama, E. F. and French, K. R. 1996. "Multifactor Explanations of Asset Pricing Anomalies". Journal of Finance 51 (1): 55-84.

Frazzini, A. and Lamont, O. A. 2008. "Dumb Money: Mutual Fund Flows and the Crosssection of Stock Returns”. Journal of Financial Economics 88 (2): 299-322.

Gharghori, P., Mudumba, S. and Veeraraghavan, M. 2007. "How Smart is Money? An Investigation into Investor Behaviour in the Australian Managed Fund Industry. Pacific-Basin Finance Journal 15 (5): 494-513.

Gharghori, P., Sujoto, C. and Veeraraghavan, M. 2008. “Are Australian Investors Smart?”. Australian Journal of Management 32 (3): 525-544.

Goetzmann, W. N. and Peles, N. 1997. "Cognitive Dissonance and Mutual Fund Investors”. Journal of Financial Research 20 (2): 145-158.

Greene, J. T. and Hodges, C. W. 2002. "The Dilution Impact of Daily Fund Flows on Openend Mutual Funds”. Journal of Financial Economics 65(1): 131-158.

Gruber, M. J. 1996. Another Puzzle: The Growth in Actively Managed Mutual Funds”. Journal of Finance 51 (3): 783-810.

Hoepner, A. G., Rammal, H. G. and Rezec, M. 2009. Islamic Mutual Funds' Financial Performance and Investment Style: Evidence from 20 Countries. Retrieved from http://ssrn.com/paper=1475037 
International Financial Services London. 2010. Islamic Finance. Retrieved from http://www.ifsl.org.uk

Ismail, A. G. and Shakrani, M. S. 2003. "The Conditional CAPM and Cross-sectional Evidence of Return and Beta for Islamic Unit Trusts in Malaysia. Journal of Economics and Management 11 (1): 1-31.

Jegadeesh, N. and Titman, S. 1993. "Returns to Buying Winners and Selling Losers: Implications for Stock Market Efficiency”. Journal of Finance 48 (1): 65-91.

Ke, D. 2006. Three Essays on Mutual Fund Investment Decisions. PhD thesis, University of Wisconsin-Milwaukee.

Keswani, A. and Stolin, D. 2008. "Which Money is Smart? Mutual Fund Buys and Sells of Individual and Institutional Investors”. Journal of Finance 63 (1): 85-118.

Marzuki, A. and Worthington, A.C. 2014. "Development of Islamic mutual funds in Malaysia”, in A.C. Worthington (ed.), Contemporary Issues in Islamic Finance: Principles, Progress, and Prospects, Nova, New York, 51-71.

Marzuki, A. and Worthington, A.C. 2015. "Shariah screening”, in Iqbal, Z. and Shafii, Z. (eds.) State of Islamic Finance: A Retrospective Assessment and Looking Forward, Universiti Sains Islam Malaysia, Bandar Baru Nilai, 223-264.

Morningstar. 2010. Morningstar. Retrieved 31 January 2010 http://www.morningstar.com.au

Nathie, M. 2009. Islamic Equity Investments: Determinants of Investment Behaviour of Malaysian Islamic Equity Investors under Conditions of Competing Alternatives. PhD thesis, Griffith University.

Odean, T. (1998). “Are Investors Reluctant to Realize Their Losses?”. Journal of Finance 53 (5): 1775-1798.

Peng, C.-L., Chen, M.-L., Shyu, S.-D. and Wei, A.-P. 2011. "When is Money Likely to be Smart? Evidence from Mutual Fund Investors in Taiwan”. Investment Analysts Journal 73 (1): 13-25.

Renneboog, L., Ter Horst, J. R. and Zhang, C. 2008. “The Price of Ethics and Stakeholder Governance: The Performance of Socially Responsible Mutual Funds”. Journal of Corporate Finance 14 (3): 302-322.

Renneboog, L., Ter Horst, J. R. and Zhang, C. 2011. "Is Ethical Money Financially Smart? Nonfinancial Attributes and Money Flows of Socially Responsible Investment Funds”. Journal of Financial Intermediation 20 (4): 562-588.

Sapp, T. and Tiwari, A. 2004. "Does Stock Return Momentum Explain the Smart Money Effect? Journal of Finance 59 (6): 2605-2622.

Securities Commission Malaysia. 2012. Securities Commission Annual Reports from 1998 to 2011. Retrieved 31 June, 2012, from http://www.sc.com.my

Shanken, J. 1990. “Intertemporal Asset Pricing: An Empirical Investigation”. Journal of Econometrics 45 (1-2): 99-120.

Sirri, E. R. and Tufano, P. 1998. "Costly Search and Mutual Fund Flows”. Journal of Finance 53 (5): 1589-1622.

ul Haq, I., Khurshed, A. and Espenlaub, S. 2011. Where did the Smart Money Go? Evidence on Fund Selection Ability amongst UK Investors. Paper presented at the European Financial Management Association Braga, Portugal.

Vicente, L., Ortiz, C. and Andreu, L. 2008. A Further Look at Investors' Abilities: 'Smart Money' or 'Smart Investors'? Paper presented at the XVI Spanish Finance Association Annual Meeting, Barcelona, Spain.

Wermers, R. R. 2003. "Is Money Really 'Smart'? New Evidence on the Relation between Mutual Fund Flows, Manager Behavior, and Performance Persistence. Retrieved from http://ssrn.com/paper=414420 doi:10.2139/ssrn.414420 
Zheng, L. 1999. “Is Money Smart? A Study of Mutual Fund Investors' Fund Selection Ability”. Journal of Finance 54 (3): 901-933. 
Table 1. Growth of Malaysian mutual fund industry, 1999-2010

\begin{tabular}{|c|c|c|c|c|c|c|c|c|c|c|c|c|}
\hline & 1999 & 2000 & 2001 & 2002 & 2003 & 2004 & 2005 & 2006 & 2007 & 2008 & 2009 & 2010 \\
\hline No. of management companies & 34 & 34 & 37 & 39 & 39 & 36 & 36 & 38 & 39 & 39 & 39 & 39 \\
\hline No. of approved funds*: & 107 & 127 & 163 & 188 & 226 & 291 & 340 & 416 & 521 & 579 & 541 & 564 \\
\hline Conventional & 94 & 110 & 132 & 144 & 171 & 220 & 257 & 316 & 387 & 430 & 397 & 412 \\
\hline Islamic & 13 & 17 & 32 & 44 & 55 & 71 & 83 & 100 & 134 & 149 & 144 & 152 \\
\hline Net asset value (NAV) (RM bil.) & 43.26 & 43.3 & 47.34 & 53.7 & 70.08 & 87.39 & 98.49 & 121.76 & 169.41 & 134.41 & 191.71 & 226.81 \\
\hline Conventional & 41.87 & 41.62 & 44.92 & 50.5 & 65.33 & 80.62 & 90.00 & 112.59 & 152.55 & 117.22 & 169.63 & 202.77 \\
\hline Islamic & 1.39 & 1.68 & 2.42 & 3.2 & 4.75 & 6.76 & 8.49 & 9.17 & 16.86 & 17.19 & 22.08 & 24.04 \\
\hline Market Capitalisation Bursa Malaysia (RM bil.) & 552.60 & 444.35 & 464.64 & 481.61 & 640.00 & 722.04 & 695.27 & 848.70 & 1106.15 & 663.80 & 999.53 & $1,275.00$ \\
\hline NAV to Bursa Malaysia market capitalisation (\%) & 7.83 & 9.74 & 10.18 & 11.15 & 10.95 & 12.1 & 14.17 & 14.35 & 15.32 & 20.25 & 19.18 & 17.79 \\
\hline
\end{tabular}

Source: Securities Commission annual report s (Securities Commission Malaysia, 2012) *Includes fund approved but not yet launched \#Not including unit holders account at IUTA that operates nominee account system

Table 2. Islamic mutual funds by asset allocation from 2006-2010

\begin{tabular}{lrrrrrrrrrr}
\hline \multirow{2}{*}{ Type of fund } & \multicolumn{2}{c}{2006} & \multicolumn{2}{c}{2007} & \multicolumn{2}{c}{2008} & \multicolumn{2}{c}{2009} & \multicolumn{2}{c}{2010} \\
& No. & NAV & No. & NAV & No. & NAV & No. & NAV & No. & NAV \\
\hline Balanced funds & 19 & 1.25 & 21 & 1.7 & 21 & 1.24 & 22 & 1.6 & 22 & 1.6 \\
Sukuk funds & 18 & 1.56 & 19 & 1.8 & 18 & 1.5 & 20 & 1.4 & 21 & 1.8 \\
Equity funds & 50 & 5.6 & 62 & 10.4 & 70 & 9 & 72 & 4.7 & 78 & 17.2 \\
Others & 13 & 0.75 & 32 & 3 & 40 & 5.45 & 36 & 4.4 & 34 & 3.4 \\
\hline Total & 100 & 9.16 & 134 & 16.9 & 149 & 17.19 & 150 & 12.1 & 155 & 24 \\
\hline
\end{tabular}

Notes: NAV in Ringgit Malaysia (RM) billion. Other funds include feeder, fixed income,

money market, structured product and mixed asset funds. Source: Securities Commission

Annual Report 2006-10 (Securities Commission Malaysia, 2012) 
Table 3. Descriptive statistics for IEFs and CEFs, 1999-2008

This table shows the distribution of the principal variables over the sample period 1999 to 2008. AGE is the number of years since inception. AUM is assets under management in millions of Malaysian Ringgits (RM). RM FLOW is the absolute change in AUM net of fund returns during the period in million. RM is Malaysian ringgit. FLOW is the proportion of annual change in AUM net of fund returns during the period divided by previous year AUM. PTR is the portfolio turnover and MER is the management expense ratio. Std. dev. is standard deviation. The total number of fund years considered is 178 and 552 for Islamic equity funds (IEFs) and conventional equity funds (CEFs), respectively.

\begin{tabular}{lrrrrrr}
\hline & \multicolumn{3}{c}{ IEF $(\mathrm{n}=34)$} & \multicolumn{3}{c}{ CEF $(\mathrm{n}=83)$} \\
\hline AGE & Mean & Median & Std. dev. & Mean & Median & Std. dev. \\
AUM & 6.89 & 4.77 & 7.07 & 11.25 & 7.91 & 9.57 \\
RM FLOW & 157.99 & 62.32 & 256.92 & 158.32 & 75.23 & 209.56 \\
FLOW & -0.11 & -0.91 & 103.23 & -19.13 & -5.92 & 66.21 \\
PTR & 13.47 & -1.50 & 83.93 & -2.63 & -10.27 & 73.38 \\
MER & 86.02 & 67.50 & 151.63 & 85.73 & 66.00 & 70.67 \\
\hline
\end{tabular}


Table 4. Summary of positive and negative flows for IEFs by year

This table shows the distribution of the principal variables over the sample period 1999 to 2008. AUM is the asset under management in millions of Malaysian Ringgit (RM). FLOW is the proportion of annual change in asset under management (AUM) net of fund returns during the period divided by previous year AUM. PTR is the portfolio turnover and MER is the management expense ratio. Std.dev. is standard deviation. Excess return is the excess return for the following year.

\begin{tabular}{|c|c|c|c|c|c|c|c|c|c|c|c|}
\hline Year & 1999 & 2000 & 2001 & 2002 & 2003 & 2004 & 2005 & 2006 & 2007 & 2008 & Total \\
\hline \multicolumn{12}{|c|}{ Positive flow } \\
\hline No. of funds & 3 & 5 & 6 & 8 & 13 & 10 & 15 & 7 & 3 & 16 & 86 \\
\hline AUM & 126.34 & 636.30 & $1,125.01$ & 1,769.19 & $2,287.41$ & $1,281.19$ & $3,101.60$ & $1,544.69$ & 635.26 & $3,340.69$ & - \\
\hline FLOW & 52.43 & 127.75 & 50.98 & 59.63 & 65.34 & 79.80 & 90.63 & 16.39 & 53.73 & 48.03 & - \\
\hline Excess return & 0.2418 & -0.2777 & 0.1449 & -0.0574 & 0.1372 & -0.0734 & -0.0034 & 0.4327 & -0.1679 & -0.0873 & - \\
\hline \multicolumn{12}{|c|}{ Negative flows } \\
\hline No. of funds & 2 & 3 & 2 & 1 & 1 & 7 & 7 & 22 & 30 & 17 & 92 \\
\hline AUM & 231.84 & 278.00 & 93.12 & 82.84 & 81.06 & $1,386.89$ & 895.93 & $2,790.59$ & $3,882.71$ & 2,551.34 & - \\
\hline FLOW & -71.11 & -23.42 & -3.58 & -3.57 & -10.41 & -19.69 & -17.28 & -25.14 & -62.35 & -18.61 & - \\
\hline Excess return & 0.1550 & -0.2736 & 0.2076 & 0.0498 & -0.0223 & -0.0612 & 0.1075 & 0.3816 & -0.1165 & -0.0080 & - \\
\hline Total IEF funds & 5 & 8 & 8 & 9 & 14 & 17 & 22 & 29 & 33 & 33 & \\
\hline
\end{tabular}

Table 5. Summary of positive and negative flows for CEFs by year

This table shows the distribution of the principal variables over the sample period 1999 to 2008. AUM is the asset under management in millions of Malaysian Ringgit (RM). FLOW is the proportion of annual change in asset under management (AUM) net of fund returns during the period divided by previous year AUM. PTR is the portfolio turnover and MER is the management expense ratio. Std.dev. is standard deviation. Excess return is the excess return for the following year.

\begin{tabular}{|c|c|c|c|c|c|c|c|c|c|c|c|}
\hline Year & 1999 & 2000 & 2001 & 2002 & 2003 & 2004 & 2005 & 2006 & 2007 & 2008 & Total \\
\hline \multicolumn{12}{|c|}{ Positive flows } \\
\hline No. of funds & 13 & 14 & 24 & 25 & 25 & 14 & 14 & 7 & 8 & 7 & 151 \\
\hline AUM & $2,833.08$ & $4,606.69$ & $5,558.42$ & $5,727.04$ & $5,799.80$ & 2,936.71 & 1,363.01 & 431.26 & 442.43 & 276.43 & - \\
\hline FLOW & 41.70 & 88.67 & 16.72 & 92.16 & 56.38 & 61.82 & 28.04 & 29.35 & 149.09 & 18.58 & - \\
\hline Excess return & 0.2470 & -0.1998 & 0.1900 & 0.0428 & 0.1085 & -0.0103 & 0.0050 & 0.4878 & -0.2182 & 0.0670 & - \\
\hline \multicolumn{12}{|c|}{ Negative flows } \\
\hline No. of funds & 18 & 21 & 20 & 25 & 28 & 42 & 49 & 70 & 65 & 63 & 401 \\
\hline AUM & $1,658.75$ & $2,485.88$ & $1,686.87$ & $3,751.68$ & $5,167.91$ & $8,522.98$ & $9,193.48$ & $9,463.91$ & $9,070.42$ & $6,414.70$ & - \\
\hline FLOW & -17.21 & -10.06 & -7.80 & -7.49 & -9.59 & -24.04 & -14.99 & -33.94 & -56.53 & -19.16 & - \\
\hline Excess return & 0.1880 & -0.2529 & 0.1326 & 0.0342 & 0.2132 & -0.0571 & 0.0789 & 0.3492 & -0.1790 & 0.0366 & - \\
\hline Total CEF funds & 31 & 35 & 44 & 50 & 53 & 56 & 63 & 77 & 73 & 70 & \\
\hline
\end{tabular}


Table 6. Descriptive statistics of IEF and CEF excess returns, 2000-2009

This table presents the descriptive statistics of 10 portfolios. The first two portfolios are average portfolios and the next eight portfolios are new money-flow portfolios constructed based on the previous year money-flows information. EW average is equally-weighted average portfolio of all available funds. VW average is value-weighted average portfolio of all available funds. EW positive flow is equally-weighted of all available funds with positive money-flows. EW negative flow is equally-weighted of all available funds with negative money-flow. VW positive flow is value-weighted of all available funds with positive money-flows (also called as positive old money-flows). VW negative flow is value weighted of all available funds with negative money-flow (also called as negative old moneyflows). MW positive is money-flow weighted of all available funds with positive money-flows. MW negative is money-flow weighted of all available funds with negative money-flows. High flow is equally-weighted of all available funds with money-flows above median. Low flow is equally-weighted of all available funds with money-flows below median.

\begin{tabular}{lccrccc}
\hline & \multicolumn{3}{c}{ IEF } & & & CEF \\
& Mean & Median & Std. dev. & Mean & Median & Std. dev. \\
\hline EW average & 0.0027 & 0.0029 & 0.0414 & 0.0031 & 0.0055 & 0.0466 \\
VW average & 0.0003 & 0.0002 & 0.0049 & 0.0001 & 0.0001 & 0.0010 \\
EW positive flow & 0.0031 & 0.0028 & 0.0402 & 0.0041 & 0.0063 & 0.0457 \\
EW negative flow & 0.0018 & 0.0030 & 0.0436 & 0.0031 & 0.0062 & 0.0476 \\
VW positive flow & 0.0012 & 0.0004 & 0.0099 & 0.0009 & 0.0005 & 0.0054 \\
VW negative flow & 0.0008 & 0.0003 & 0.0183 & 0.0001 & 0.0001 & 0.0018 \\
MW positive flow & 0.0013 & 0.0005 & 0.0096 & 0.0009 & 0.0006 & 0.0055 \\
MW negative flow & 0.0009 & 0.0003 & 0.0184 & 0.0001 & 0.0001 & 0.0018 \\
High flow & 0.0030 & 0.0047 & 0.0396 & 0.0031 & 0.0072 & 0.0454 \\
Low flow & 0.0023 & 0.0032 & 0.0439 & 0.0032 & 0.0054 & 0.0481 \\
Market portfolio & 0.0048 & 0.0073 & 0.0527 & - & - & - \\
Risk-free rate & 0.0023 & 0.0023 & 0.0004 & - & - & - \\
\hline
\end{tabular}


Table 7. Performance of positive and negative money-flow portfolios

This table presents the alpha estimates of the Fama-French (1993) three-factor and the Carhart (1997) four-factor models of positive and negative money-flow portfolios for Malaysian IEFs (columns 2 to 4), CEFs (columns 5 to 7) and the differences in the estimates between IEFs and CEFs (columns 8 to 10). In Panel A, we construct these money-flow portfolios based on the previous year net money-flows (positive or negative) and weighted equally by the number of funds in the portfolio. The table also reports the equally-weighted average portfolios, the difference in the estimated alphas between the positive and negative portfolios, and between positive and average portfolios. Panel A.1 and Panel A.2 present the alpha estimates of the three-factor and four-factor models, respectively. We identically arrange the alpha estimates in Panel B with exception that we use money-flow weighted instead of equally-weighted and the average portfolio is the value (asset under management)-weighted average portfolios. Coef. is alpha coefficient. Std. err. is the standard error. The standard errors are NeweyWest adjusted.

\begin{tabular}{|c|c|c|c|c|c|c|c|c|c|}
\hline & \multicolumn{3}{|c|}{ IEF } & \multicolumn{3}{|c|}{ CEF } & \multicolumn{3}{|c|}{ IEF-CEF } \\
\hline & Coef. & $\begin{array}{l}\text { Std. } \\
\text { err. }\end{array}$ & $\begin{array}{c}\mathrm{p}- \\
\text { value }\end{array}$ & Coef. & Std. err. & p-value & Coef. & Std. err. & $\mathrm{p}$-value \\
\hline & \multicolumn{9}{|c|}{ Panel A: Equally-weighted portfolios } \\
\hline Positive & 0.0003 & 0.0011 & 0.8132 & 0.0004 & 0.0011 & 0.6822 & -0.0002 & 0.0011 & 0.8785 \\
\hline Negative & -0.0010 & 0.0013 & 0.4182 & -0.0007 & 0.0006 & 0.2590 & -0.0003 & 0.0013 & 0.7949 \\
\hline Average & -0.0003 & 0.0010 & 0.7478 & -0.0005 & 0.0006 & 0.4118 & 0.0002 & 0.0008 & 0.7898 \\
\hline Positive vs. negative & 0.0013 & 0.0014 & 0.3557 & 0.0011 & 0.0009 & 0.2174 & 0.0002 & 0.0016 & 0.9220 \\
\hline \multirow[t]{2}{*}{ Positive vs. average } & 0.0006 & 0.0005 & 0.2875 & 0.0010 & 0.0008 & 0.2212 & -0.0004 & 0.0009 & 0.6689 \\
\hline & \multicolumn{9}{|c|}{ Panel A.2. Four-factor alpha } \\
\hline Positive & -0.0003 & 0.0012 & 0.8385 & -0.0003 & 0.0010 & 0.7438 & 0.0001 & 0.0011 & 0.9399 \\
\hline Negative & -0.0018 & 0.0012 & 0.1469 & -0.0010 & 0.0006 & 0.1156 & -0.0008 & 0.0012 & 0.4996 \\
\hline Average & -0.0009 & 0.0011 & 0.4108 & -0.0010 & 0.0007 & 0.1312 & 0.0001 & 0.0008 & 0.9285 \\
\hline Positive vs. negative & 0.0016 & 0.0013 & 0.2329 & 0.0007 & 0.0009 & 0.4622 & 0.0009 & 0.0014 & 0.5289 \\
\hline \multirow[t]{3}{*}{ Positive vs. average } & 0.0007 & 0.0005 & 0.1851 & 0.0007 & 0.0008 & 0.3864 & 0.0000 & 0.0009 & 0.9902 \\
\hline & \multicolumn{9}{|c|}{ Panel B: Money-flow weighted portfolios } \\
\hline & \multicolumn{9}{|c|}{ Panel B.1. Three-factor alpha } \\
\hline Positive & 0.0010 & 0.0006 & 0.1155 & 0.0007 & 0.0003 & 0.0364 & 0.0002 & 0.0004 & 0.5922 \\
\hline Negative & -0.0005 & 0.0011 & 0.6327 & 0.0000 & 0.0001 & 0.5386 & -0.0005 & 0.0010 & 0.6494 \\
\hline Average & 0.0000 & 0.0002 & 0.8805 & 0.0000 & 0.0000 & 0.7120 & 0.0000 & 0.0002 & 0.9171 \\
\hline Positive vs. negative & 0.0015 & 0.0012 & 0.2387 & 0.0008 & 0.0004 & 0.0417 & 0.0007 & 0.0010 & 0.4731 \\
\hline \multirow[t]{2}{*}{ Positive vs. average } & 0.0010 & 0.0006 & 0.0830 & 0.0008 & 0.0003 & 0.0313 & 0.0003 & 0.0004 & 0.4700 \\
\hline & \multicolumn{9}{|c|}{ Panel B.2. Four-factor alpha } \\
\hline Positive & 0.0005 & 0.0005 & 0.3599 & 0.0006 & 0.0004 & 0.0750 & -0.0001 & 0.0004 & 0.7115 \\
\hline Negative & -0.0009 & 0.0011 & 0.3973 & -0.0001 & 0.0001 & 0.3604 & -0.0009 & 0.0010 & 0.4163 \\
\hline Average & -0.0002 & 0.0002 & 0.1584 & 0.0000 & 0.0000 & 0.2858 & -0.0002 & 0.0002 & 0.1804 \\
\hline Positive vs. negative & 0.0014 & 0.0013 & 0.2766 & 0.0007 & 0.0004 & 0.0743 & 0.0007 & 0.0010 & 0.4932 \\
\hline Positive vs. average & 0.0007 & 0.0005 & 0.1651 & 0.0007 & 0.0004 & 0.0579 & 0.0001 & 0.0003 & 0.8650 \\
\hline
\end{tabular}


Table 8. Performance of new versus old money flow portfolios

This table presents the alpha estimates of the Fama-French (1993) three-factor and the Carhart (1997) four-factor models of new and old money-flow portfolios for Malaysian IEFs (columns 2 to 4 ), CEFs (columns 5 to 7 ) and the differences in the estimates between IEFs and CEFs (columns 8 to 10). Panel A reports the positive new money-flow, positive old money-flow and the difference in the estimated alphas between the positive new and old money-flow portfolios. The positive new money-flow portfolios are the money-flow weighted of all available funds with positive new money-flow. The positive old money-flow portfolios are the value (asset under management (AUM))-weighted (previous year AUM before the new flow) of all available funds with positive new money-flow portfolio. We construct these new money-flow portfolios based on the previous year net money-flows. Panel A.1 and Panel A.2 present the alpha estimates of the three-factor and four-factor models, respectively. We identically arrange the alpha estimates in Panel B with exception that we use negative money-flow instead of positive money-flow portfolios. Coef. is alpha coefficient. Std. err. is the standard error. The standard errors are Newey-West adjusted.

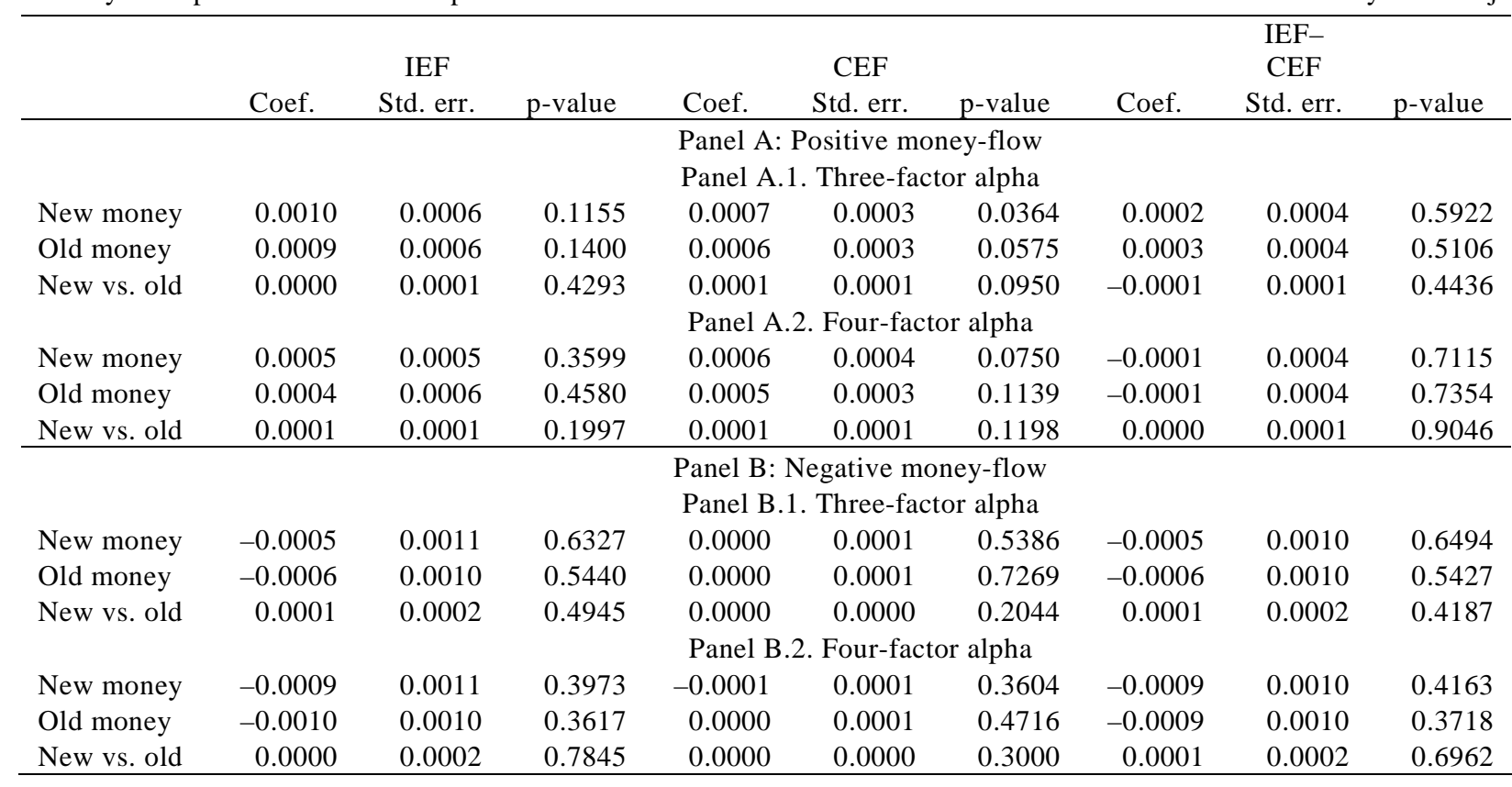


Table 9. Performance of high versus low money flow portfolios

This table presents the alpha estimates of the Fama-French (1993) three-factor and the Carhart (1997) four-factor models of high and low money-flow portfolios for Malaysian IEFs (columns 2 to 4), CEFs (columns 5 to 7) and the differences in the estimates between IEFs and CEFs (columns 8 to 10). The table also reports the equally-weighted average portfolios, the difference in the estimated alphas between the high and low portfolios, and between high and the equally-weighted average portfolios. We construct these new moneyflow portfolios based on the previous year net money-flows. The high money-flow portfolio refers to the portfolio consists of funds with net new money-flows above the median value for a particular year. Likewise, the low money-flow portfolio refers to all other funds that do not fit the previous criteria. Panel A and Panel B present the alpha estimates of the three-factor and four-factor models, respectively. Coef. is alpha coefficient. Std. err. is the standard error. The standard errors are Newey-West adjusted.

\begin{tabular}{|c|c|c|c|c|c|c|c|c|c|}
\hline & Coef. & $\begin{array}{l}\text { IEF } \\
\text { Std. } \\
\text { err. }\end{array}$ & p-value & Coef. & $\begin{array}{l}\text { CEF } \\
\text { Std. } \\
\text { err. }\end{array}$ & p-value & Coef. & $\begin{array}{c}\text { IEF-CEF } \\
\text { Std. } \\
\text { err. }\end{array}$ & p-value \\
\hline & \multicolumn{9}{|c|}{ Panel A. Three-factor alpha } \\
\hline High flow & 0.0003 & 0.0013 & 0.8114 & -0.0002 & 0.0008 & 0.7915 & 0.0005 & 0.0010 & 0.6029 \\
\hline Low flow & -0.0010 & 0.0009 & 0.3054 & -0.0008 & 0.0006 & 0.1959 & -0.0002 & 0.0010 & 0.8441 \\
\hline Average & -0.0003 & 0.0010 & 0.7478 & -0.0005 & -0.0006 & 0.4118 & 0.0002 & 0.0008 & 0.7898 \\
\hline High vs. low & 0.0013 & 0.0012 & 0.2827 & 0.0006 & 0.0007 & 0.4394 & 0.0007 & 0.0012 & 0.5424 \\
\hline \multirow[t]{2}{*}{ High vs. av. } & 0.0006 & 0.0006 & 0.3353 & 0.0003 & 0.0004 & 0.4289 & 0.0003 & 0.0006 & 0.6346 \\
\hline & \multicolumn{9}{|c|}{ Panel B. Four-factor alpha } \\
\hline High flow & 0.0000 & 0.0014 & 0.9732 & -0.0008 & 0.0009 & 0.3542 & 0.0008 & 0.0010 & 0.3816 \\
\hline Low flow & -0.0019 & 0.0010 & 0.0671 & -0.0011 & 0.0006 & 0.0654 & -0.0007 & 0.0010 & 0.4529 \\
\hline Average & -0.0009 & 0.0011 & 0.4108 & -0.0010 & 0.0007 & 0.1312 & 0.0001 & 0.0008 & 0.9285 \\
\hline High vs. low & 0.0019 & 0.0011 & 0.0832 & 0.0003 & 0.0008 & 0.6523 & 0.0016 & 0.0010 & 0.1246 \\
\hline High vs. av. & 0.0010 & 0.0006 & 0.1060 & 0.0002 & 0.0004 & 0.6138 & 0.0008 & 0.0006 & 0.1845 \\
\hline
\end{tabular}

